\section{PNA-Based Light-Up Probes for Real-Time Detection of Sequence- Specific PCR Products}

\author{
BioTechniques 31:766-771 (October 2001)
}

\begin{abstract}
The aim of this study was to introduce the use of a peptide nucleic acid (PNA)-thiazole orange conjugate for real-time monitoring of PCR. When the so-called light-up probes hybridize sequence-specifically to the PCR product, an increase in the fluorescent signal is obtained. It was found that the light-up probe can quantitatively measure the amount of DNA or intact bacterial cells in the reaction mixture, without interfering with the PCR amplification. A linear detection range of at least 4 log units was obtained without optimization of the system. The detection limit of this light-up assay per reaction mixture was $0.4 \mathrm{pg}$ genomic
\end{abstract} Yersinia enterocolitica DNA.

\section{INTRODUCTION}

Recently, new techniques have been developed for rapid and quantitative PCR without the risk of carry-over contamination $(9,18,20)$. These real-time techniques are based on either sequence-specific DNA probes or dyes, such as $\mathrm{SYBR}^{\circledR}$ Green I, that detect any dsDNA, regardless of the nucleotide sequence. One of the most recent developments in this area is the use of peptide nucleic acid (PNA) probes for PCR detection (11).

PNA is a synthetic achiral nucleic acid in which the sugar-phosphate backbone of DNA is replaced by uncharged peptide-like $\mathrm{N}$-(2-aminoethyl) glycine units $(5,10)$. PNA-DNA duplexes have a higher thermal stability than the corresponding DNA-DNA duplexes (4). This is mainly due to the lack of electrostatic repulsion between the PNA strand and its target DNA. Furthermore, the binding of PNA to DNA is specific because a mismatch is more thermally destabilizing than its corresponding DNADNA duplex (4). So far, the excellent hybridization properties and the high thermal stability of PNA in combination with PCR have mainly been exploited for PCR clamping $(3,7)$. The use of PNA instead of DNA for probes also has the advantage that the uncharged backbone of the PNA leads to an increase in the independence of the system to salt concentration $(13,15)$. The uncharged properties of PNA may be an advantage when complex biological matrices are used as PCR samples (2). Thus, the sequence specificity of PNA and its insensitivity to changes in salt concentration make its application to probe technology very interesting.

The so-called light-up probe consisting of a PNA oligonucleotide linked to an asymmetric cyanine dye has recently been developed for sequencespecific detection of DNA for molecular diagnostic purposes (16). For instance, light-up probe technology has been used for the detection of purified Salmonella DNA by conventional PCR (6). The aim of this study was to com bine real-time PCR technology with the light-up probe system to allow the detection of purified DNA and intact cells of Yersinia enterocolitica.

\section{MATERIALS AND METHODS}

\section{Real-Time PCR Conditions}

Two primer pairs from a multiplex PCR assay for $Y$. enterocolitica (8) were used to illustrate the usefulness of a PNA-based light-up probe in the LightCycler $^{\mathrm{TM}}$ system (Roche Molecular Biochemicals, Mannheim, Germany). The first primer pair, which amplifies a 0.60$\mathrm{kb}$ part of the plasmid-borne virulence gene $y a d A$, generated a target for the light-up probe. The probe was synthesized as previously described by Svanvik et al. (16) and consisted of the dye thiazole orange (TO), which was linked with a five-carbon-chain linker to a 12mer PNA oligonucleotide, TO-CTCCATCTTTCT-Lys. The lysine moiety was attached to the carboxyl end of the PNA to increase its water solubility. The second primer pair, amplifying a 0.30 $\mathrm{kb}$ fragment, was used to illustrate the behavior of the light-up probe during amplification of non-target DNA. Tem plate DNA was prepared by extracting
DNA from 24-h cultures of $Y$. enterocolitica O:3 Y79 (The Norwegian School of Veterinary Sciences, Oslo, Norway) in TSB (Trypton Soya Broth, Oxoid, CM129, Basingstoke, UK) grown at $28^{\circ} \mathrm{C}$. The reaction mixture $(20 \mu \mathrm{L})$ for real-time measurements in the LightCycler contained $0.75 \mathrm{U}$ Taq DNA polymerase (Roche Molecular Biochemicals), $1 \times$ PCR buffer (Roche Molecular Biochemicals), $4 \mathrm{mM} \mathrm{MgCl} 2,0.4 \mu \mathrm{M}$ each primer, $0.2 \mathrm{mM}$ each dATP, dCTP, dTTP, dGTP, $1 \mu \mathrm{M}$ light-up probe, and $4 \mu \mathrm{L}$ sample. The samples consisted of either purified DNA or intact $Y$. enterocolitica cells in physiological saline. Each amplification started with a denaturation step for $30 \mathrm{~s}$ at $95^{\circ} \mathrm{C}$, followed by 40 cycles of $0.1 \mathrm{~s}$ denaturation at $95^{\circ} \mathrm{C}, 5 \mathrm{~s}$ annealing at $60^{\circ} \mathrm{C}$, followed by a single fluorescence measurement, and finally $25 \mathrm{~s}$ elongation at $72^{\circ} \mathrm{C}$. Am plification was completed with one cooling step for $1 \mathrm{~min}$ at $40^{\circ} \mathrm{C}$. After amplification, the DNA products were visualized on an ethidium bromidestained $1.3 \%$ agarose gel. During amplification, the fluorescence was measured using the following gain settings: F1:80, F2:15, F3:30, display mode F1. After amplification, the crossing point value (Cp) of the reaction was determined

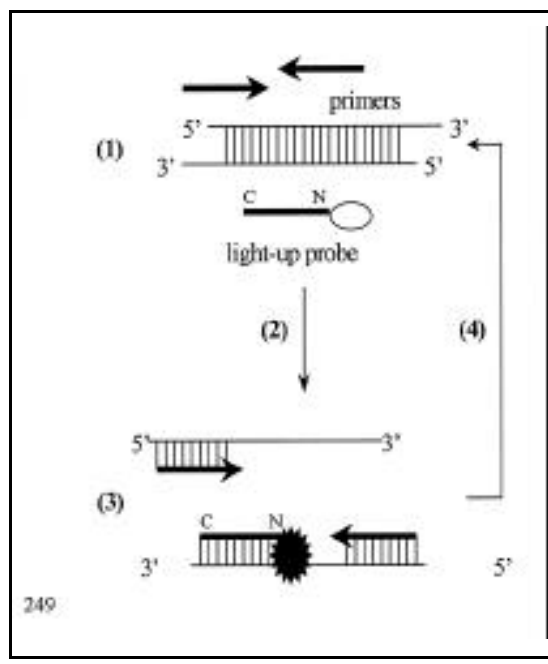

Figure 1. The principle of real-time PCR and light-up technology. (1) Excess of free primers and unbound light-up probe. (2) Target DNA sequences are separated by heat denaturation. (3) PCR primers and light-up probe anneal to ssDNA when the temperature is lowered to the annealing temperature, followed by a fluorescence measurement. (4) Release of the light-up probe and DNA synthesis of new target DNA at the elongation temperature. 
using the second derivative method of the LightCycler software, version 3.0. The value of $\mathrm{Cp}$ is defined as the cycle in which the fluorescence significantly increases above the background because of the formation of amplified products (7). Also, the relative fluorescence was determined by the ratio between the fluorescence readings with and without template DNA. Each of the amplification results given was obtained from at least two independent experiments.

\section{RESULTS}

No PCR inhibition was observed when $1 \mu \mathrm{M}$ light-up probe was present during amplification (data not shown). The fluorescence was measured after the primer annealing step, as is illustrated in Figure 1. The measurement was performed after this step because no fluorescent signal above the background fluorescence could be monitored during the elongation and denaturation steps of PCR. The melting point of the light-up probe-DNA duplex was determined to be $66^{\circ} \mathrm{C}$ by measuring the UV absorbance at $260 \mathrm{~nm}$.

The detection limit of the light-up probe was $0.4 \mathrm{pg}$ DNA per reaction tube when three independent 10 -fold

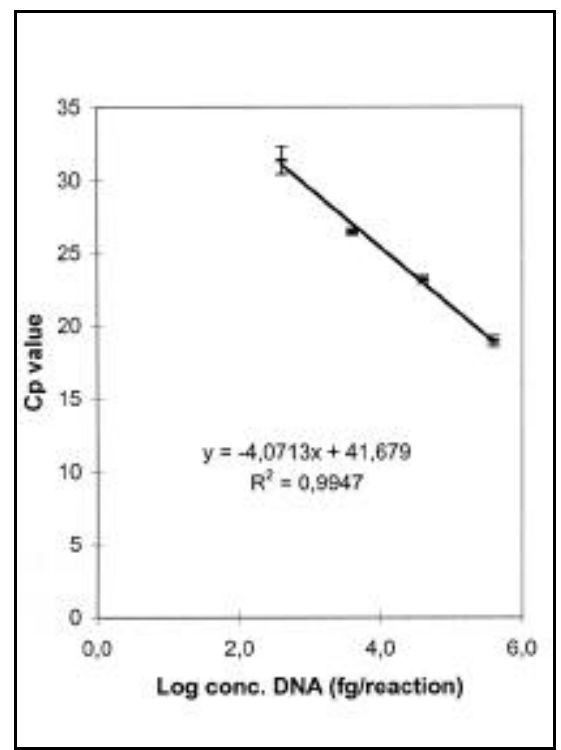

Figure 2. Plot of Cp (cycle number in which the fluorescence increases for the first time above a threshold value) against the input DNA concentration. Error bars show the standard deviation $(n=3)$. serial dilutions were tested. Figure 2 shows that a linear relationship was obtained over at least $4 \log$ units when the DNA concentration was plotted versus the $\mathrm{Cp}$ value.

Figure 3 shows the difference between the increase in relative fluorescence upon the amplification of lightup target DNA [part of the yadA gene of $Y$. enterocolitica (8)] and non-target DNA [part of the $16 \mathrm{~S}$ rRNA gene of $Y$. enterocolitica (8)]. As the sample for amplification, whole $Y$. enterocolitica cells were used instead of purified DNA. Finally, when measuring the fluorescence of the probes in samples without DNA or Yersinia cells, it could be concluded that the level of background fluorescence was below $1 \%$ of the end-point fluorescence values.

\section{DISCUSSION}

PNA is known to form very stable complexes with DNA, and this is exploited in PCR clamping $(3,12,17)$. In PCR clamping, PNA binds to non-mismatch template DNA and inhibits am plification, as the DNA polymerase cannot hydrolyze PNA oligonucleotides. In this assay, the light-up probe did not hybridize near the PCR primers, which is usually the case when PNA is used for clamping $(7,17)$. Since there was no inhibition of the amplification and because no fluorescent signal was observed after the elongation phase, the results indicated that the probes were not hybridized to the DNA template during the elongation phase of the amplification $\left(72^{\circ} \mathrm{C}\right)$. This was confirmed by determining the melting tem perature of the probe, which was $66^{\circ} \mathrm{C}$.

Concerning the sensitivity, the results are comparable those of other real-time PCR detection systems using DNA probes $(1,14,19)$ and was three $\log$ units greater that that of the PNA molecular beacons system (11). Other advantages of light-up probe technology when compared with other PNAbased systems such as PNA molecular beacons may be that it is a one-dye system and that the probes do not have to undergo structural changes, as do the molecular beacons upon hybridization.

Regarding the sequence specificity, Svanvik et al. (16) demonstrated that 


\section{Short Technical Reports}

light-up probes can distinguish between PCR products that contain one single mismatch. This was in agreement with the lack of increase in fluorescence when non-target DNA was amplified (Figure 3). However, further studies are needed to investigate possible sequence dependency of the mismatch discrimi-

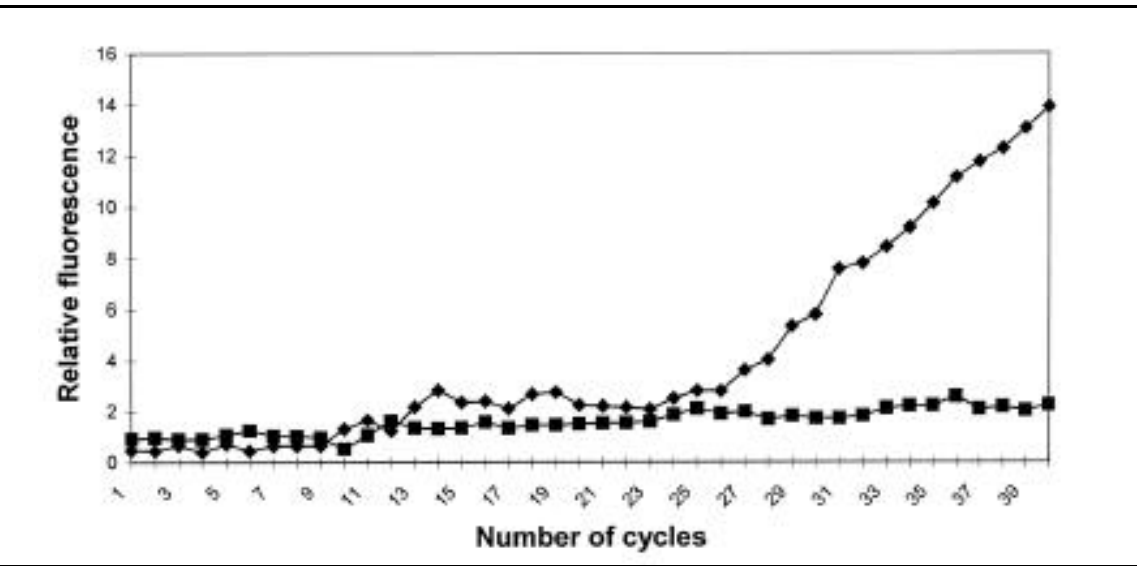

Figure 3. The sequence specificity of the light-up probe. The relative fluorescence during amplification of light-up target DNA and non-target DNA from $10^{8} \mathrm{CFU}$ Y. enterocolitica/mL with a set of primers for the yadA gene $(\diamond)$ and a set of primers for the 16S rRNA gene (๘). The light-up probe was designed for an internal sequence of the yadA gene. nation and the behavior of the light-up probes in complex matrices. The low background fluorescence $(<1 \%)$ can be explained by the fact that there is no electrostatic interaction between the TO and the PNA oligonucleotide (16), which results in only minimal backbinding of the probe to itself.

In conclusion, this study shows that, with a suitable probe design, light-up probes do not inhibit DNA amplification, as might have been expected from PCR clamping studies. The results indicated that sensitivity comparable to that of current real-time detection systems can be obtained without extensive optimization. However, a more systematic comparison between existing real-time technologies and light-up probe technology is necessary for the critical evaluation of the relative effectiveness of different probe systems. Bearing in mind the tolerance of PNA to changes in salt concentration, the results indi- 
cate that this system might be well suited for direct detection of targets in com plex biological samples. We have demonstrated that intact bacterial cells can be used as PCR samples instead of purified DNA. In conclusion, light-up technology is a new promising detection system for real-time, sequence-specific analysis of amplified nucleic acids.

\section{REFERENCES}

1.Abe, A., K. Inoue, T. Tanaka, J. Kato, N. Kajiyama, R. Kawaguchi, S. Tanaka, M. Yoshiba, and M. Kohara. 1999. Quantitation of hepatitis B virus genomic DNA by real-time detection PCR. J. Clin. Microbiol. 37:28992903.

2.Abu Al-Soud, W. and P. Rådström. 1998. Capacity of nine thermostable DNA polymerases to mediate DNA amplification in the presence of PCR-inhibiting samples. Appl. Environ. Microbiol. 64:3748-3753.

3.Demers, D.B., E.T. Curry, M. Egholm, and A.C. Sozer. 1995. Enhanced PCR amplification of VNTR locus D1S80 using peptide nucleic acid (PNA). Nucleic Acids Res. 23:30503055 .

4.Egholm, M., O. Buchardt, L. Christensen, C. Behrens, S.M. Freier, D.A. Driver, R.H. Berg, S.K. Kim, B. Norden, and P.E. Nielsen. 1993. PNA hybridizes to complementary oligonucleotides obeying the Watson-Crick hydrogen-bonding rules. Nature 365:566-568.

5.Frank-Kamenetskii, M. 1991. Oligonucleotide drugs. A change of backbone. Nature 354:505.

6.Isacsson, J., H. Cao, L. Ohlsson, S. Nordgren, N. Svanvik, G. Westman, M. Kubista, R. Sjoback, and U. Sehlstedt. 2000. Rapid and specific detection of PCR products using light-up probes. Mol. Cell Probes 14:321-328.

7.Kyger, E.M., M.D. Krevolin, and M.J. Pow ell. 1998. Detection of the hereditary hemochromatosis gene mutation by real-time fluorescence polymerase chain reaction and peptide nucleic acid clamping. Anal. Biochem. 260:142-148.

8.Lantz, P.G., R. Knutsson, Y. Blixt, W.A. Al Soud, E. Borch, and P. Rådström. 1998. Detection of pathogenic Yersinia enterocolitica in enrichment media and pork by a multiplex PCR: a study of sample preparation and PCRinhibitory components. Int. J. Food Microbiol. 45:93-105.

9.Livak, K.J., S.J. Flood, J. Marmaro, W. Giusti, and K. Deetz. 1995. Oligonucleotides with fluorescent dyes at opposite ends provide a quenched probe system useful for detecting PCR product and nucleic acid hybridization. PCR Methods Appl. 4:357-362.

10.Nielsen, P.E., M. Egholm, R.H. Berg, and O. Buchardt. 1991. Sequence-selective recognition of DNA by strand displacement with a thymine-substituted polyamide. Science 254:1497-1500.

11.Ortiz, E., G. Estrada, and P.M. Lizardi. 1998. PNA molecular beacons for rapid detec- tion of PCR amplicons. Mol. Cell Probes 12:219-226.

12.Ørum, H., P.E. Nielsen, M. Egholm, R.H. Berg, O. Buchardt, and C. Stanley. 1993. Single base pair mutation analysis by PNA directed PCR clamping. Nucleic Acids Res. 21:5332-5336.

13.Ørum, H., P.E. Nielsen, M. Jorgensen, C. Larsson, C. Stanley, and T. Koch. 1995. Sequence-specific purification of nucleic acids by PNA-controlled hybrid selection. BioTechniques 19:472-480.

14.Pahl, A., U. Kuhlbrandt, K. Brune, M. Rollinghoff, and A. Gessner. 1999. Quantitative detection of Borrelia burgdorferi by realtime PCR. J. Clin. Microbiol. 37:1958-1963.

15.Perry-O'Keefe, H., X. W. Yao, J. M. Coull, M. Fuchs, and M. Egholm. 1996. Peptide nucleic acid pre-gel hybridization: an alternative to Southern hybridization. Proc. Natl. Acad. Sci. USA 93:14670-14675.

16.Svanvik, N., G. Westman, D. Wang, and M. Kubista. 2000. Light-up probes; thiazole orange conjugated PNA for detection of target nucleic acid in homogeneous solution. Anal. Biochem. 281:26-35.

17.von Wintzingerode, F., O. Landt, A. Ehrlich, and U.B. Gobel. 2000. Peptide nucleic acidmediated PCR clamping as a useful supplement in the determination of microbial diversity. Appl. Environ. Microbiol. 66:549-557.

18. Wittwer, C.T., M.G. Herrmann, A.A. Moss, and R.P. Rasmussen. 1997. Continuous fluorescence monitoring of rapid cycle DNA am plification. BioTechniques 22:134-138.

19.Wittwer, C.T., K.M. Ririe, R.V. Andrew, D.A. David, R.A. Gundry, and U.J. Balis. 1997. The LightCycler: a microvolume multisample fluorimeter with rapid temperature control. BioTechniques 22:176-181.

20.Woo, T.H., B.K. Patel, L.D. Smythe, M.A. Norris, M.L. Symonds, and M.F. Dohnt. 1998. Identification of pathogenic Leptospira by TaqMan probe in a LightCycler. Anal. Biochem. 256:132-134.

This work was financially supported by the Commission of the European Communities within the program "Quality of Life and Management of Living Resources", QLK11999-00226. Address correspondence to Dr. Peter Rådström, Applied Microbiology, Center for Chemistry and Chemical Engineering, Lund Institute of Technology, Lund University, P.O. Box 124, SE-22100, Sweden.e-mail:peter.radstrom@tmb.lth.se

Received 14 November 2000; accepted 25 April 2001

\section{Petra Wolffs, Rickard Knutsson, Robert Sjöback ${ }^{1}$, and Peter Rådström \\ Lund University, Lund \\ ${ }^{1}$ Diffchamb $A B$ \\ Hisings Backa, Sweden}

